\title{
School Leadership. Models and Tools: A Review
}

\author{
Vasileios Gougas*, Lucia Malinova \\ Department of Preschool and Media Pedagogy, Faculty of Science, Education and Arts, St. Kliment Ohridski University of Sofia, \\ Sofia, Bulgaria \\ Email: ^bgougas@gmail.com
}

How to cite this paper: Gougas, V., \& Malinova, L. (2021). School Leadership. Models and Tools: A Review. Open Journal of Social Sciences, 9, 120-139. https://doi.org/10.4236/jss.2021.91009

Received: December 6, 2020

Accepted: January 15, 2021

Published: January 18, 2021

Copyright $\odot 2021$ by author(s) and Scientific Research Publishing Inc. This work is licensed under the Creative Commons Attribution International License (CC BY 4.0).

http://creativecommons.org/licenses/by/4.0/

\begin{abstract}
Many researchers have dealt with school leadership because of the rapid development of educational change. The leadership's influence in shaping the reforms and improving the quality of education, as well as in the job satisfaction of the teachers and the successful operation of the school unit is catalytic and at the same time regulatory. For this reason, a number of tools for measuring school leadership have been implemented. Some of the tools have their roots in the management of companies and organizations while others have been implemented exclusively for the management of school units. In this review, a reference is made to the leadership models that one can encounter in a school unit but also to the tools that can be used to measure leadership depending on the model encountered. The purpose of this study is to contribute to the literature with the presence of tools used to measure the behavior of different leadership styles. There is a brief presentation of each tool, the dimensions it captures, the leadership style it measures as well as its degree of reliability. The review showed that tools such as MLQ, LPI, PIMRS, CLIO, GLOBE and DLI can be used with great ease.
\end{abstract}

\section{Keywords}

School Leaders, Leadership Measuring Tools, Leadership Models, Questionnaire

\section{Introduction}

The contemporary school is a competitive organization, which incorporates elements and sets goals that a few years ago seemed unthinkable. It is a participatory, multifaceted school, where knowledge seems to be a secondary choice, as values such as technological ones prevail, and the successful are counted according to their abilities and skills. This mutation simply reflects our society, which in recent years has been structured in an environment of versatility, where everyone knows everything, can do everything and the difference lies in the way the 
means are used, which gives a form of specialization. In this fluid environment, the role of the school principal as a leader becomes crucial.

The role of school managers in education is crucial, although discredited in the educational hierarchy, for the proper functioning of the schools they run. They are the visionaries, the ones who capture and inspire a vision for the future of their school units and together with their collaborators the teachers are called to realize it. At the same time, they are the ones responsible for the proper functioning of the school unit, the educators who draw the guidelines, the animating spirits of teachers and students, the coordinators of the efforts, the people who solve any problem that arises in the school unit, the bureaucrats who represent the central government, the financially accountable for the proper management of the unit's resources, the innovation rapporteurs, those responsible for the personal and professional development of teachers. Finally, they are the connecting links of all the groups that make up the school unit, the collaborators of all, but also the final liable for any negligence or unfortunate incident that arises in the educational unit they lead. Therefore, their role has a multidimensional character and concerns not only their direct collaborators, but also reflects on a wider part of society.

From the above, it becomes obvious that high training of leaders is required at pedagogical and organizational-administrative level, in order to acquire all the necessary skills and abilities that will enable them to effectively manage their schools and to consolidate the vision they have for them.

\section{Leadership Models}

To be considered effective, a leader must be possessed of characteristics and behaviours that aid him in his difficult role. They should be able to create the right work environment and promote teamwork. In this context and over the years several management theories have been developed, many of which stem from the experience of the management of organizations and companies. According to the bibliography it is possible to meet the following leadership models:

Transformational Leadership: It consists of four elements (Bass et al., 2003) which, if available, the leader successfully implements the specific model. The leader should have a vision for the school organization, monitor the individual needs of his subordinates acting sometimes as an educator and sometimes as a mentor, motivate and urge the subordinates to change their way of thinking in order to solve problems and convey optimism and enthusiasm to teachers.

Transactional Leadership: Its principal idea is the conciliation or exchange of rewards and/or punishments between the leader and the subordinates (Yammarino et al., 1993). The leader of this style does not want and does not seek change and innovation but the maintenance of the status quo.

Charismatic Leadership: The leader should have the right character, temperament, charisma to positively influence subordinates and convey values, visions, ideals. A charismatic leader can achieve the sympathy, trust, acceptance of 
members and their involvement in the decision-making process. A big problem for many researchers is equating the charismatic leader with the transformational leader. According to Bass et al., (2003) charisma is a part of transformational leadership. A transformational leader does not have to be charismatic, that is, they are two distinct concepts (Yukl, 1999).

Passive leadership such as Laissez-faire/Management by exception leadership is essentially an absence of power as the leader avoids making decisions, is absent and makes no effort to meet the needs of subordinates. The leader does not take action, does not prevent situations and only intervenes when the problems are chronic.

Distributed Leadership: The leader distributes responsibilities and tries to activate as many of the team members as possible. The best-case scenario is to activate the whole team. With the division of responsibilities, each person assumes the leadership in a specific area for the period of time that the specific tasks have been assigned to him. In the school reality, the distributed administration includes the active cooperation for the implementation of events, the connection of the school unit with the local community and the evaluation of the students. Essentially the manager behaves as the first among equals. The interest in this leadership model came as a reaction to the models that overemphasized the role of the leader in relation to other teachers, because there is a belief that the role of the principal as the sole leader in a school unit is now a thing of the past (Hulpia et al., 2011).

Ethical/Moral Leadership: A key element is the ethics of the leader. The school cannot be governed by the same management logic that governs organizations and businesses where the goal is solely profit. In business, all decisions and practices work and move according to it. The school, however, aims to develop students' personalities and cultivate democratic values (Wong, 1998). Therefore, the values and beliefs of the leader play an important role because the ethical principles, habits and beliefs of the leader determine the way in which the leader exercises leadership.

Contingent/Situational Leadership: This leadership model is based on the assumption that no leadership model is a panacea, that is, it is not effective in all situations that will arise in a school unit. Therefore, leaders depending on the situation can change the leadership model and use it according to the situation. Depending on the situation, leaders respond with a different leadership model.

Post-modern Leadership: All involved (leader and subordinates) have the right to express themselves and be heard on issues that concern and interest them. Leaders-as in participative leadership_facilitate the involvement of members of the school community. Postmodern leadership focuses on the subjective experiences of leaders and subordinates as well as the different interpretations given by individuals.

Emotional Leadership: It is based on the emotional intelligence of the leader. The leader with emotional intelligence has the ability to perceive the perspective 
of others, the ability to distinguish as well as appropriate response to the moods of other people. Has the ability to achieve a high rate of transmission and response of emotions with facial expressions, voice and gestures (Goleman, 2001). It is emerged as a higher order concept of transformational intelligence (Habib et al., 2020).

Instructional Leadership: The leader takes action to improve student learning. Emphasizes the interaction of leader and students. A key role of the leader is to assist, support and facilitate both teaching and learning. According to the prevailing model of pedagogical leadership of Hallinger and Murphy (1987) the leader should a) define the mission of the school, b) coordinate and control the teaching by monitoring the progress of the students, $c$ ) improve the school climate and teacher professional development. It requires increased scientific knowledge from the manager and therefore can lead to unsuccessful leadership (Leithwood et al., 1999).

Participative Leadership: The leader in participative leadership functions more as a colleague as he leads among equals and manages professionals. His/her main task is to achieve consensus among those involved who must share responsibility for decisions (Baldridge et al., 1978). The model is based, according to Leithwood et al., (1999), on the assumption that participation improves school effectiveness, reflects democratic values, and that the self-governing school unit provides the opportunity for leadership to any legitimate stakeholder. When people are involved in the decision-making process, they are more likely to adopt and implement that decision, especially when it is directly related to their personal work (Copland, 2001).

Servant Leadership: It is the type of leadership in which the leader puts himself at the service of all members of the collaborative team seeking to meet their needs and thus ensure their commitment that they will pursue the goals of the organization with all their forces. The educational leader in the service leadership can be the means of improving the work efficiency of the organization's members because of three qualities he/she provides to them: a) the ability to teach in a student audience by improving the skilfulness of their teaching practice, b) the provision of standards that assist teachers in their work and in improving their teaching; and c) the technique of verbal persuasion that enables teachers to communicate and gain the trust or results they desire without invoking the power provided by their position (Bandura, 1997). In summary, service leadership incorporates elements from other leadership models with key references to pedagogical, transformational, distributed, ethical and interpersonal leadership, giving a missing dimension to all of them, the placement of the employees by the leader above him/herself.

\section{Literature Review}

The manager in a business or organization, as well as in a school unit performs a very important task. In the case of schools, his work is more dynamic because it 
relates to both existing teachers and students. Also, the frequent changes that take place in the field of education and the various reforms have a significant impact on the way a school is run.

The models often overlap conceptually and due to their indistinguishable characteristics, it is not possible to divide a leader into a single category because his/her characteristics fall into another or more categories. It is also difficult to describe the limits of each model which, although it should stop at the limits of another, forms infinite variations that are very difficult to delineate. An important element that also makes clear definition difficult is the change of meaning in common meanings depending on the type of leadership to which they are addressed, that is, their examination from a different perspective (Hater \& Bass, 1988; Leithwood \& Duke, 1999; Bush \& Glover, 2003). For this reason, many researchers have implemented various measuring tools of the respective leadership model.

It is of crucial importance that the future researcher measuring leadership characteristics has grouped the various tools that have been implemented and used in various surveys to capture the behavioral characteristics of leaders in order to finally decide on the tool to use or whether to proceed with the implementation of a new tool that will meet his research needs. For this reason, a bibliographic review of the research that has taken place in the last twenty years and the tools used in them is presented. There is a small presentation of the tool, with the leadership style that is counted, through the different dimensions of leadership behavior.

MLQ 5x (Multifactor Leadership Questionnaire): One of the tools used to measure the characteristics and leadership behaviour of school principals is the MLQ-5x as developed by Avolio and Bass (2004). This tool consists of 45 questions of the five-point scale $0-4$. Specifically, 20 questions that are divided into 5 sub-scales measure transformational leadership. Transactional Leadership is measured through 12 questions divided into 3 subscales while finally Laissezfaire/Management by exception leadership is measured through 4 questions. The last 9 questions of the tool calculate the leadership outcome. Charisma in this tool is measured (Antonakis, et al., 2016) as an endogenous variable. It is called idealized influence having (Antonakis et al, 2016) with both behavioural and attributional contribution to transformational leadership (Antonakis, 2012). It appears that this tool has been used in most research and has been translated and calibrated in many languages.

TLI (Transformational Leadership Behavior Inventory): This scale was created by Podsakoff et al., (1990) in order to capture transformational leadership through 22 questions on the Linkert $1-5$ scale. The questions capture the 6 main behaviours that a transformational leader should have: a) Inspiring others with his vision (3 questions), b) Defining a model to be followed by the subordinates (3 questions), c) Promoting cooperation and achieving of the goal (4 questions), d) High performance expectations on the part of participants (3 questions), e) Recognition and support of individual needs and feelings (4 questions), f) Guid- 
ing subordinates in redefining their assumptions and way they think (3 questions). As in the case of MLQ, this tool measures charisma as an endogenous variable.

PLQ (Principal Leadership Questionnaire): Jantzi and Leithwood, (1996) created this scale to capture transformational leadership through 24 questions on the Linkert 1 - 6 scale. The questions capture the 6 main dimensions of a transformational leader: a) Identifying Vision (5 questions), b) Modelling (3 questions), c) Goal Acceptance (5 questions), d) High Expectations (3 questions), e) Individualized support (5 questions), f) Intellectual Stimulation (3 questions).

TLQ (Transformational Leadership Questionnaire): This scale by Alimo-Metcalfe and Alban-Metcalfe, (2001) was implemented to capture transformational leadership through 9 different dimensions and 76 questions: a) Genuine concern (Alban-Metcalfe \& Alimo-Metcalfe, 2000a) for others (17 questions), b) Political sensitivity (Alimo-Metcalfe \& Alban-Metcalfe, 2001) and skills (6 questions), c) Decisiveness, determination (Alban-Metcalfe \& Alimo-Metcalfe, 2000b), selfconfidence (8 questions), d) Integrity, trustworthy (Alimo-Metcalfe \& AlbanMetcalfe, 2001), honest (9 questions), e) Empowers (Alban-Metcalfe \& AlimoMetcalfe, 2000b), developing potential (8 questions), f) Inspirational networker \& promoter (10 questions), g) Accessible (Alimo-Metcalfe \& Alban-Metcalfe, 2001), approachable (6 questions), h) Clarifies boundaries (Alban-Metcalfe \& Alimo-Metcalfe, 2000a), involves others in decisions (5 questions), i) Encourages critical (Alimo-Metcalfe \& Alban-Metcalfe, 2001) and strategic thinking (7 questions). As in the case of MLQ, this tool measures charisma as an endogenous variable.

The Nature of School Leadership: It is part of the "Organizational Conditions and School Leadership Survey" questionnaire (Leithwood \& Jantzi, 1999) with 270 questions that measure both the conditions prevailing in a school and the transformational leadership style. Leadership style is measured through a 53-item on a Likert 1 - 5 scale questionnaire. It consists of ten dimensions, six of which refer to leadership and four to management: a) Symbolizing Professional Practices and Values (6 questions), b) Developing Structures in School Decisions (6 questions), c) Offering Individualized Support (4 questions), d) Providing Intellectual Stimulation (7 questions), e) Demonstrating High Performance Expectations (3 questions), f) Building School Vision and Goals (6 questions), g) Establishing Effective Staff Practices (6 questions), h) Providing Instructional Support (5 questions), i) Monitoring School Activities (5 questions), j) Providing a Community Focus (5 questions).

GTL (Global Transformational Leadership Scale): It is a short and clear onedimensional scale (Carless et al., 2000), providing a short measure compatible with the theoretical concepts of transformational leadership. It consists of 17 questions. Each question examines one of the seven leader behaviours: a) vision, that is whether the leader has a positive vision for the future, b) staff development, that is whether the leader treats team members as individuals and whether he supports their development, c) supportive leadership, whether the leader re- 
cognizes and encourages the efforts of team members, d) empowering, whether the leader cultivates a sense of cooperation and trust, e) innovating thinking, whether the problem-solving leader strengthens and encourages the finding of new innovative solutions $f$ ) leading by example, whether it is clear to everyone what he seeks through the practices he applies and g) charisma, whether he exudes respect and pride and inspires others. Participants respond on a Likert scale 0 - 4. As in the case of MLQ, this tool measures charisma as an endogenous variable.

DLI (Distributed Leadership Inventory): It is used to capture distributed leadership in a school unit. According to Hulpia et al., (2009) the scales that were used in the survey were based on the following dimensions: strength of vision, supportive leadership behaviour, providing instructional support, providing intellectual stimulation team (Hulpia \& Devos, 2016), supervising and monitoring teachers, role ambiguity, group cohesion team (Hulpia et al., 2012), degree of goal consensus team (Hulpia \& Devos, 2016)) and last but not least expertise of the leadership team (Hulpia et al., 2012; Hulpia \& Devos, 2010). The 23 questions of the Likert scale 0 - 4 are divided into the following factors: a) Support (10 questions), b) Supervision (3 questions), c) Cohesive Leadership Team (10 questions).

SPLIT (Shared Professional Leadership Inventory for Teams): Grille and Kauffeld, (2015) created this scale. It consists of 20 questions of scale 1 - 6 Likert belonging to 4 dimensions of 5 questions. Specifically: a) task leadership orientation (Grille \& Kauffeld, 2015), b) relation leadership orientation, c) change leadership orientation (Kozusznik et al., 2018), and d) micro political leadership orientation (Kozusznik et al., 2018). With the help of this tool, the size of distributed leadership is captured.

EL (Ethical Leadership): The first psychometric tool created by Khuntia and Suar (2004) and named EL. The tool included 22 elements, which emphasised significantly on two dimensions: "empowerment" and "motivation and character". More specifically, the first 12 elements of the scale focused on the empowerment factor, while the remaining ten elements focused on the motivation and character factor.

ELS (Ethical Leadership Scale): The first scale based on a general dimension for ethical leadership, created by Brown, Treviño, and Harrison (2005). The final version of the scale follows the method of hetero-evaluation and consists of 10 elements. An example of this was: "My boss makes fair and balanced decisions". The response scale used for the ELS was a five-point rating scale ( 1 = "Strongly disagree" to 5 = "Strongly agree").

ELI (Ethical Leadership Inventory): Researchers Spangenberg and Theron (2005) created a new psychometric scale called ELI, which incorporates a large number of dimensions of ethical leadership, as it is the only scale that includes six basic dimensions and 19 sub-dimensions of ethical leadership. The final form of the ELI consists of 101 questions.

ELBS (Ethical Leadership Behavioural Scale): Tanner et al. (2010) created a new psychometric tool for hetero-evaluation, which was based on the conceptual 
approach of Brown and Trevino, (2006) trying to overcome the semantic limitations and syntactic ambiguities of the ELS scale elements. It consists of 35 questions. A typical example of a question on this scale is: Admits when he or she does not know how to carry out a task. The response scale used was a threepoint rating scale ("Strongly Disagree", up to "Strongly Agree").

ELW (Ethical Leadership Questionnaire at Work): Created by Kalshoven et al., (2011), who proceeded to empirically document a multidimensional conceptual model for ethical leadership.

ELM (Ethical Leadership (Measure): Researchers Zheng et al., (2011) sought to evaluate the ethical and unethical behaviour of leaders at work. The new conceptual model of ethical leadership they proposed includes three dimensions, which are named: a) individual ethical characteristics, b) ethical decision-making style and c) ethical standard construction. The psychometric tool was based on the thoughts of the Chinese philosopher Confucius. It consists of 14 questions, which significantly charged the three factors. The response scale used was a five-point rating scale ( $1=$ "Not at all" to $5=$ "Often, if not always").

ELQ (Ethical Leadership Questionnaire): Yukl et al., (2013) in an effort to improve the conceptual model of ethical leadership, created a new scale of hetero-evaluation. It is divided into four dimensions: a) honesty and integrity (Virakul, 2018), b) behaviour intended to communicate (Virakul, 2018) or enforce ethical standards (Yukl, et al., 2013), c) fairness in decisions and the distribution of rewards (Yukl, et al., 2013) and finally behaviour that shows compassion (Cheteni \& Shindika, 2017) and concern for the needs and feelings of others (Yukl, et al., 2013). The response scale used was a five-point rating scale ( $1=$ "Strongly disagree" to 5 = "Strongly agree") and included 15 questions.

EMLQ (Empowering leadership questionnaire): This questionnaire (Arnold et al., 2000) measures the dimensions of empowering leadership. According to Sagnak (2016); Miao et al., (2014); Huang et al., (2006); Huang et al. (2010); Bell et al., (2014); Bell \& Mjoli, (2014); Odoardi et al., (2019); Bhatti et al., (2019); Ghaffari et al., (2017); Fatima et al., (2017) six of the questions of this tool are also used to measure participant leadership. The tool consists of 5 categories and a total of 38 questions. The answers to this questionnaire are given on a 5-point scale, where the values start from 1 which corresponds to "never" and reaches up to 5 which corresponds to "always". These values indicate whether a leader adopts these behaviours. In detail, the categories are: 1) leading by example which consists of 5 questions, 2) coaching; a set of behaviours in which team members are trained and help them gain confidence by assessing their weaknesses, consists of 11 questions, 3) participative decision making; the specific category has to do with the fact that in order to make a decision, the information and data of all the members of the team are taken, since there is freedom of expressing their views and ideas. It consists of 6 questions and is used as a scale for measuring participant leadership (Sagnak 2016; Miao et al., 2014; Huang et al., 2006; Huang et al. 2010; Bell et al., 2014; Bell \& Mjoli, 2014; Odoardi et al., 2019; Bhatti et al., 2019; 
Ghaffari et al., 2017; Fatima et al., 2017), 4) informing; refers to the wide dissemination of important information through the leader related to the business, such as is its philosophy or mission, with 6 questions and 5) showing interest; it is a set of behaviours that show respect for the well-being of team members, with 10 questions. This tool has been used in a large number of studies in recent years.

SLS (Servant Leadership Scale based on Patterson theory, 2003): According to the above theory, servant leadership is structured around the following axes: a) love, with its social, moral concept, where the individual is treated as a complete personality with needs and desires, b) altruism; the ability to stand next to each other without personal gain, making personal sacrifice (Kaplan, 2000), c) humanity; one's ability to maintain his/her positive points in perspective (Sandage \& Wiens, 2001), d) vision; the action or power of the imagination, a way of seeing and perceiving what will come in the future, e) trust, that we feel for someone regarding his character and ability (Hauser \& House, 2000). It consists of 26 sentences of 5 grades (Likert type), which team members are asked to answer if the specific sentences correspond to the actions, behavior and thinking of the leaders. This scale is characterized by validity (Dennis \& Bocarnea, 2005).

ESLS (Executive Servant Leadership Scale): Consists of 25 questions (Reed et al., 2011) on the 4-point Likert scale. It reflects the dimensions of servant leadership: a) interpersonal support (6 questions); whether the leader helps members to develop their potential, b) building community, encouraging spirit of cooperation and organizational commitment (5 questions), c) Altruism (4 questions), d) Egalitarianism, which welcomes criticism, encourages debate ideas and learns from others (4 questions), e) moral integrity, such as trust, honesty, integrity, refusing to use manipulation (6 questions).

ILI (Instructional Leadership Inventory): Consists of 23 Linkert five-point questions (Alig-Mielcarek \& Hoy, 2005). It measures the three main characteristics of Instructional Leadership: a) leader behaviors (7 questions) that promote professional development, b) developing and communicating (8 questions) with teachers in order to achieve goals collaboratively, c) monitoring and providing feedback (8 questions) on teaching and learning process.

PIMRS (Principal Instructional Management Rating Scale): This questionnaire (Hallinger, 1983, 1990) measures instructional leadership through 50 Likert 1-5 scale questions that identify its three dimensions Defining School Mission, Managing the Instructional Program and Developing School Learning Climate (Pan et al., 2015). The first dimension consists of the subcategories Frames the goals" and "Communicates the goals" (Pan et al., 2015). The second dimension refers to the subcategories "Monitors student progress", "Supervises and evaluates" and "Coordinates the curriculum" (Hallinger et al., 1994). Finally, the last dimension consists of the subcategories "Protects time", "Provides incentives for teacher", "Provides incentives for learners" (Hallinger et al., 1994), "Promotes professional development" and lastly "Maintains high visibility" (Pan 
et al., 2015). The PIMRS ratings do not, however, measure the quality of instructional leadership (Hallinger et al., 1994). It has been used in over 131 studies primarily in the USA.

ELQ (Emotional Leadership Questionnaire): Consists of 51 questions (Goleman et al., 2002) on a Likert scale of 1-5. It captures the 4 dimensions of emotional intelligence by Goleman et al., (2002). Each dimension consists of a different number of questions and features. More specifically: a) Self-awareness (3 characteristics and 8 questions), b) self-management (6 characteristics and 20 questions), c) social awareness (3 characteristics and 7 questions), d) relationship management (6 characteristics and 16 questions).

C-K Scale (Conger and Kanoungo Scale by Conger \& Kanoungo, 1992): Consists of 25 questions on a Likert scale of 1 - 6. It measures the six behavioural dimensions of a charismatic leader (Conger et al., 1997): a) environmental sensitivity; whether the leader is aware of the opportunities and constants of the environment, b) sensitivity to needs; how much the leader is followed and sensitized by needs of his subordinates, c) does not maintain whether the leader is trying to find new ways of approach, d) vision where in this dimension the vision of the leader and his special role in relation to the role of others is measured, e) personal risk, whether the leader has created those conditions where the subordinate is able to take risks to achieve the goals and f) unconventional behavior where the leader in order to achieve the goals, he/she is able to develop innovative and original ways of action.

LPC (Least Preferred Coworker): This scale (Fiedler, 1995) is used by a leader to capture the extent of contingency leadership he/she applies. It consists of 18 questions with bipolar rating ( 8 to 1 , friendly to unfriendly). For the correct completion the leader should think of all his subordinates and choose the one with whom the cooperation is considered more difficult. The sum of the points is also the total LPC score. According to the scale, in order to develop his effectiveness, the leader must modify and re-evaluate the situations related to the questions to which he gave extreme values ( 1 or 2 or 3 or 8 ) (Chester \& Neider, 2006).

SOLA (Servant Organizational Leadership Assessment): It is a tool (Laub, 1999) for capturing the percentage of servant leadership in a team through six dimensions: a) values people which means that the leader shows love, acceptance, faith or trust in subordinates, b) develops people; whether the leader provides the appropriate environment for the development of subordinates, c) builds community; whether the leader works with the team, d) displays authenticity; showing honest behavior, accepting criticism and admitting mistakes and omissions, e) provides leadership; giving a vision and clear goals and f) shares leadership; strengthening and positively influencing the team without demanding honors and positions. The scale consists of 60 questions. Every question includes four values (Essential, Necessary, Desirable, Unnecessary) placed at regular intervals on a seven-point scale.

LSQ (Leadership Style Questionnaire): It was implemented by Northouse, 
(2001) in order to measure characteristics of transactional leadership as well as of transformational leadership. The survey consists of 20 questions where the odd numbered items (total ten questions) deal with transactional leadership and the even numbered items (total ten questions) deal with transformational leadership. It uses a standard 5-point Likert type scale (1. Strongly disagree and 5. Strongly agree).

LPI (Leader Practices Inventory): It was demonstrated by Kouzes and Posner, (1988, 2002, 2012) Captures leadership style through 30 Likert questions that correspond to 5 factors. It has two versions, for the leader as well as for the observer (employee). The statements are measured on a ten-point Likert scale. Each version measures five leadership practices: a) Model the way (6 items) by setting an example for others to follow; b) inspire a vision (6 items); c) challenge the process (6 items) as they take risks and experiment (Prabaswari \& Dharmastiti, 2019); d) enable others to act (6 items) as they make the appropriate working climate so that every person can feel strong and capable (Prabaswari \& Dharmastiti, 2019); e) encourage the heart (6 items) as they recognize everyone's work and contribution to the procedure (Kouzes \& Posner, 2012). According to Posner (2016); Kouzes and Posner (2012) LPI scale is based on transformational leadership model through the analysis of thousands of case studies. Results support the usage of LPI to measure transformation and transactional leadership in educational units (Fields \& Herold, 1997). As in the case of MLQ, this tool measures charisma as an endogenous variable.

GLOBE (Global Leadership and Organizational Behavior Scale): This scale was implemented in order to assess twenty one dimensions of leadership. Data from 62 countries all over the world were used. It consists of 100 questions that are rated on a seven point Likert-type scale that ranged from a low of "This behavior or characteristic greatly inhibits a person from being an outstanding leader" (Mączyński et al., 2010) to a high of "This behavior or characteristic contributes greatly to a person being an outstanding leader" (Mączyński et al., 2010; Resick et al., 2006). It can be used in order to measure behaviors of charismatic, transactional, transformational, ethical and participative leadership (Resick et al., 2006; Hanges \& Dickson, 1999).

CLIO (Charismatic Leadership Organizations): It was created by de Hoogh et al., (2004) in order to measure behaviors of charismatic leadership, transformational leadership, transactional leadership and passive leadership (de Hoogh et al., 2005). Each leadership style consists of a different number of questions that measure behaviors. More specifically: a) Charismatic leadership (11 questions same as transformational leadership), b) transactional leadership (6 questions). The 27 statements are measured on a seven-point Likert scale (1. Strongly disagree up to 7 . Strongly agree).

\section{Findings}

Literature reviews of the last twenty years have shown that more than 25 tools 
have been used in research. The larger number of tools refers to measuring the main characteristics of transformational leadership. An increase in tools that capture ethical leadership-related behaviors is also noted. Obviously the choice of the appropriate tool depends on the characteristics that the researcher wants to capture. A summary of leadership behavior measurement tools is displayed in the Table 1.

The MLQ 5x, TLI, PLQ, TLQ, The Nature, GTL tools include questions related to the principles of transformational leadership such as vision, support, guiding, cooperation, defining model, and high-performance expectations. Specifically, MLQ, TLI, PLQ directly capture these dimensions while TLQ, The Nature, and GTL subcategorize one or more of the above dimensions. The LPI uses 5 dimensions since the support dimension is contained in the questions of the dimensions "challenge the process" and "enable others to act".

Instructional Leadership can be measured using the PIMRS and ILI tools, through three dimensions: a) behavior, b) communicating, and c) monitoring. The PIMRS tool is more detailed by measuring each dimension through multiple queries and has been calibrated in many different language versions.

Ethical Leadership can be measured using several tools that have been implemented in recent years. It is based on the depiction of the leader's ethics through different dimensions, some of which are based on philosophical or even religious principles. The various tools try to capture dimensions such as character, motivation, empowerment, relationship management, social management, behavior. The ELI tool contains the largest analysis of the above dimensions.

In recent years, DLI and SPLIT tools have been used in various research to capture Distributed Leadership. The DLI tool has been used in most of these surveys and has been translated and calibrated in some languages. It captures leadership through more dimensions compared to the SPLIT tool.

Table 1. Tools and Leadership models.

\begin{tabular}{cl}
\hline Leadership Model & \\
\hline Passive & MLQ, CLIO \\
Transactional & MLQ, LPI, LSQ, CLIO, GLOBE \\
Transformational & MLQ, TLI, PLQ, TLQ, LPI, Nature of School Leadership, GTL, \\
LSQ, CLIO, GLOBE & EL, ELS, ELI, ELBS, ELW, ELM, ELQ, GLOBE \\
Ethical & C-K, CLIO, GLOBE \\
Charismatic & DLI, SPLIT \\
Distributed & SLS, ESLS, SOLA \\
Servant & EMLQ, GLOBE \\
Participative & ELQ \\
Emotional & LPC \\
Contingent & ILI, PIMRS \\
Instructional &
\end{tabular}


According to Laub, (1999) it takes about 20 minutes for a survey participant to answer 80 questions on a Likert scale of $1-5$. Therefore, by reduction, for every 10 of questions 2.5 minutes are needed. The time of completing the questionnaire is an important factor for the reliability and validity of a survey because if a survey is not conducted in a mixed way or by live completion of the questionnaires but is instead conducted by sending them electronically to the participants. All of the above obviously on the one hand increase the sample of the research and on the other hand its validity and reliability. Table 2 below lists the tools and the estimated time to complete them. The data at Table 2, show that some tools need "enough" time, while others are "relatively fast" to complete.

Cronbach's alpha is used in many surveys. Table 3 below shows the alpha range for each dimension per tool. The alpha scale reliability is a measure of internal consistency of scale and values above 0.70 indicate satisfactory reliability

Table 2. Estimated time.

\begin{tabular}{ccc}
\hline Number & Models & Estimated time (min) \\
\hline $10-19$ & GTL, ELS, ELM, ELQ, LPC, EL & 3 \\
$20-29$ & TLT, PLQ, DLI, SPLIT, EL, SLS, ESLS, ILI, C-K Scale, LSQ, CLIO & 6 \\
$30-39$ & ELBS, EMLQ, LPI & 8 \\
$40-49$ & MLQ 5x & 10 \\
$50-59$ & The Nature, PIMRS, ELQ & 14 \\
$60-69$ & SOLA & 15 \\
$70-79$ & TLQ & 18 \\
$>100$ & ELI, GLOBE & 20 \\
\hline
\end{tabular}

Table 3. Cronbach's alpha range per tool.

\begin{tabular}{cccc}
\hline Tool & alpha & Tool & alpha \\
\hline CLIO & $0.81-0.86$ & PIMRS & $0.78-0.90$ \\
GLOBE & $0.66-0.76$ & ILI & $0.88-0.97$ \\
LPI & $0.81-0.93$ & ESLS & $0.90-0.94$ \\
LSQ & $0.73-0.88$ & SLS & 0.98 \\
SOLA & $0.90-0.93$ & EMLQ & 0.89 \\
C-K & $0.74-0.87$ & ELQ & $0.61-0.87$ \\
ELQ & $0.61-0.92$ & ELM & $0.74-0.90$ \\
GTL & $0.90-0.96$ & TLQ & $0.77-0.97$ \\
MLQ 5x & $0.73-0.95$ & TLI & $0.87-0.96$ \\
ELW & $0.69-0.87$ & EL & $0.90-0.96$ \\
ELBS & $0.95-0.96$ & SPLIT & $0.81-0.93$ \\
ELI & $0.79-0.89$ & DLI & $0.79-0.91$ \\
ELS & $0.90-0.94$ & PLQ & $0.77-0.94$ \\
The Nature & 0.94 & &
\end{tabular}


(Fornell \& Larker, 1981; Nunnally \& Bernstein, 1994). According to Bagozzi and Yi, (1988) a value of 0.60 and above is satisfactory. The findings show that the above tools meet the reliability specifications.

Most of the research that has been done in the last twenty years has used tools such as MLQ 5x, LPI, PIMRS and this is due to the fact that they have been translated into many languages, therefore they are friendly to the researcher and also due to the fact that some tools such as MLQ 5x have the ability to capture the dimensions of not only one leadership style but more.

\section{Conclusion}

In this study, a reference was made to the various models that can be found in a school unit but also to the tools used to capture it. For many years, several studies have been conducted worldwide related to the impact of leadership on the educational environment. The learning environment is quite dynamic because it consists of four pillars which are the leader, the subordinate teacher, the student and the parents. For the implementation of the optimal educational process, the best possible coexistence and cooperation between the above constants is important and the leader of a school unit holds a prominent position.

Choosing the right leadership style measurement tool primarily depends on the type of leadership that the researcher wants to capture. The vast majority of surveys have used the MLQ 5x and PIMRS tools. The great advantage of MLQ 5x is that on the one hand, it has been translated and calibrated in many languages and on the other hand that it can be used for Transformational, Transactional, and Passive Leadership. In the case of Transformational Leadership-which has won the largest amount of research to date-the LPI tool has been used in many studies and has also been translated into many languages. Due to their structure and the ability to measure different leadership styles, it is worth using the CLIO and GLOBE tools. However, these tools also have some disadvantages. GLOBE has a large number of questions and the CLIO tool has not been used in many countries or continents other than the European in order to capture the results from heterogeneous environments.

The data of this study are based on literature references of approximately the last twenty years that were conducted to measure leadership style. A description of the models and a kind of evaluation was made based on the reliability index and the number of responses through the presentation of their characteristics from other individual surveys. The aim of a future study is to evaluate several of these tools through a common sample of the educational community so that these tools are compared quantitatively, qualitatively to find possible correlations and overlaps between them so that the future researcher has a thorough view of the tool that he should use in his own research.

\section{Conflicts of Interest}

The authors declare no conflicts of interest regarding the publication of this paper. 


\section{References}

Alban-Metcalfe, R. J., \& Alimo-Metcalfe, B. (2000a). An Analysis of the Convergent and Discriminant Validity of the Transformational Leadership Questionnaire. International Journal of Selection and Assessment, 8, 158-175. https://doi.org/10.1111/1468-2389.00144

Alban-Metcalfe, R. J., \& Alimo-Metcalfe, B. (2000b). The Transformational Leadership Questionnaire (TLQ-LGV): A Convergent and Discriminant Validation Study. Leadership \& Organization Development Journal, 2, 280-296. https://doi.org/10.1108/01437730010343077

Alig-Mielcarek, J., \& Hoy, W. K. (2005). Instructional Leadership: Its Nature, Meaning, and Influence. In W. Hoy, \& C. Miskel (Eds.), Educational Leadership and Reform (pp. 29-51). Greenwich: Information Age Publishing.

Alimo-Metcalfe, B., \& Alban-Metcalfe, R. J. (2001). The Development of a New Transformational Leadership Questionnaire. Journal of Occupational and Organizational Psychology, 74, 1-27. https://doi.org/10.1348/096317901167208

Antonakis, J. (2012). Transformational and Charismatic Leadership. In D. V. Day, \& J. Antonakis (Eds.), The Nature of Leadership (pp. 256-88). Thousand Oaks, CA: Sage Publications.

Antonakis, J., Bastardoz, N., Jacquart, P., \& Shamir, B. (2016). Charisma: An Ill-Defined and Ill-Measured Gift. Annual Review of Organizational Psychology and Organizational Behavior, 3, 293-319. https://doi.org/10.1146/annurev-orgpsych-041015-062305

Arnold, J. A., Arad, S., Rhoades, J. A., \& Drasgow, F. (2000). The Empowering Leadership Questionnaire: The Construction and Validation of a New Scale for Measuring Leader Behaviors. Organizational Behavavior, 21, 249-269. https://doi.org/10.1002/(SICI)1099-1379(200005)21:3<249::AID-JOB10>3.0.CO;2-\#

Avolio, B. J., \& Bass, B. M. (2004). Multifactor Leadership Questionnaire. Manual and Sampler Set (3rd ed.). Redwood City, CA: Mindgarden.

Bagozzi, R. P., \& Yi, Y. (1988). On the Evaluation of Structural Equation Models. Academy of Marketing Science, 16, 79-94. https://doi.org/10.1007/BF02723327

Baldridge, J. V., Curtis, D. V., Ecker, G., \& Riley, G. L. (1978). Policy-Making and Effective Leadership. San Francisco, CA: Jossey Bass.

Bandura, A. (1997). Self-Efficacy: The Exercise of Control. New York: W.H Freeman Company.

Bass, B., Avolio, B., Jung, D., \& Berson, Y. (2003). Predicting Unit Performance by Assessing Transformational and Transactional Leadership. The Journal of Applied Psychology, 88, 207-218. https://doi.org/10.1037/0021-9010.88.2.207

Bell, C., \& Mjoli, T. (2014). The Effects of Participative Leadership on Organisational Commitment: Comparing Its Effects on Two Gender Groups among Bank Clerks. African Journal of Business Management, 8, 451-459. https://doi.org/10.5897/AJBM2013.7028

Bell, C., Chan, M., \& Nel, P. (2014). The Impact of Participative and Directive Leadership on Organisational Culture: An Organisational Development Perspective. Mediterranean Journal of Social Sciences, 5, 1970-1985. https://doi.org/10.5901/mjss.2014.v5n23p1970

Bhatti, M., Ju, Y., Akram, U., Bhatti, M., Akram, Z., \& Bilal, M. (2019). Impact of Participative Leadership on Organizational Citizenship Behavior: Mediating Role of Trust and Moderating Role of Continuance Commitment: Evidence from the Pakistan Hotel Industry. Sustainability, 11, 1170. https://doi.org/10.3390/su11041170 
Brown, M. E., \& Treviño, L. K. (2006). Ethical Leadership: A Review and Future Directions. The Leadership Quarterly, 17, 595-616.

https://doi.org/10.1016/j.leaqua.2006.10.004

Brown, M. E., Treviño, L. K., \& Harrison, D. A. (2005). Ethical Leadership: A Social Learning Perspective for Construct Development and Testing. Organizational Behavior and Human Decision Processes, 97, 117-134. https://doi.org/10.1016/j.obhdp.2005.03.002

Bush, T., \& Glover, D. (2003) School Leadership: Concepts \& Evidence. Nottingham: National College for School Leadership.

Carless, S. A., Wearing, A. J., \& Mann, L. (2000). A Short Measure of Transformational Leadership. Journal of Business and Psychology, 14, 389-405. https://doi.org/10.1023/A:1022991115523

Chester, S., \& Neider, L. (2006). Least Preferred Coworker Theory. In Encyclopedia of Industrial and Organizational Psychology (pp. 451-453). Thousand Oaks, CA: SAGE.

Cheteni, P., \& Shindika, E. S. (2017). Ethical Leadership in South Africa and Botswana. Brazilian Administration Review, 14, 2-17. https://doi.org/10.1590/1807-7692bar2017160077

Conger, J. A., \& Kanungo, R. N. (1992). Perceived Behavioral Attributes of Charismatic Leadership. Canadian Journal of Behavioural Science, 24, 86-102. https://doi.org/10.1037/h0078703

Conger, J. A., Kanungo, R. N., Menon, S., \& Mathur, P. (1997). Measuring Charisma: Dimensionality and Validity of the Conger-Kanungo Scale of Charismatic Leadership. Canadian Journal of Administrative Sciences, 14, 290-301. https://doi.org/10.1111/j.1936-4490.1997.tb00136.x

Copland, M. (2001). The Myth of the Superprincipal. Phi Delta Kappan, 82, 528-532. https://doi.org/10.1177/003172170108200710

De Hoogh, A. H. B., Den Hartog, D. N., \& Koopman, P. (2005). Linking the Big FiveFactors of Personality to Charismatic and Transactional Leadership; Perceived Dynamic Work Environment as a Moderator. Journal of Organizational Behavior, 26, 839-865. https://doi.org/10.1002/job.344

De Hoogh, A. H. B., Den Hartog, D. N., \& Koopman, P. L. (2004). De ontwikkeling van de CLIO: Een vragenlijst voor charismatisch leiderschap in organisaties. Gedrag \& Organisatie, 17, 354-382.

Dennis, R. S., \& Bocarnea, M. (2005). Development of the Servant Leadership Assessment Instrument. Leadership \& Organization Development Journal, 26, 600-615. https://doi.org/10.1108/01437730510633692

Fatima, T., Majeed, M., \& Saeed, I. (2017). Does Participative Leadership Promote Innovative Work Behavior: The Moderated Mediation Model. Business \& Economic Review, 9, 139-156. https://doi.org/10.22547/BER/9.4.7

Fiedler, F. E. (1995). Cognitive Resources and Leadership Performance. Applied Psychology, 44, 5-28. https://doi.org/10.1111/j.1464-0597.1995.tb01378.x

Fields, D., \& Herold, D. (1997). Using the Leadership Practices Inventory to Measure Transformational and Transactional Leadership. Educational and Psychological Measurement, 57, 569-579. https://doi.org/10.1177/0013164497057004003

Fornell, C., \& Larcker, D. F. (1981). Evaluating Structural Equation Models with Unobservable Variables and Measurement Error. Journal of Marketing Research, 18, 39-50. https://doi.org/10.1177/002224378101800104

Ghaffari, S., Shah, I., Burgoyne, J., \& Aziz, J. (2017). The Influence of Motivation on Job 
Performance: A Case Study at Universiti Teknologi Malaysia. Australian Journal of Basic and Applied Sciences, 11, 92-99.

Goleman, D., Boyatzis, R., \& McKee, A. (2002). Primal Leadership: Realizing the Power of Emotional Intelligence. Boston, MA: Harvard Business School Press.

Goleman, G. (2001). Leadership That Gets Results. Harvard Business Review, 35, 78-90.

Grille, A., \& Kauffeld, S. (2015). Development and Preliminary Validation of the Shared Professional Leadership Inventory for Teams (SPLIT). Psychology, 6, 75-92. https://doi.org/10.4236/psych.2015.61008

Habib, N., Awan, S. H., Naveed, S., \& Shoaib Akhtar, C. (2020). Effectiveness of Interpersonal Leadership for Engagement and Task Performance of Nurses. SAGE Open, 10, 1-15. https://doi.org/10.1177/2158244020924429

Hallinger, P. (1983, 1990). Principal Instructional Management Rating Scale. Version 2.3. Sarasota, FL: Leading Development Associates.

Hallinger, P., \& Murphy, F. J. (1987). Assessing and Developing Principal Instructional Leadership. Educational Leadership, 45, 55-61. https://doi.org/10.1007/978-90-481-9106-2 5

Hallinger, P., Taraseina, P., \& Miller, J. (1994). Assessing the Instructional Leadership of Secondary School Principals in Thailand. School Effectiveness and School Improvement, 5, 321-348. https://doi.org/10.1080/0924345940050401

Hanges, P. J., \& Dickson, M. W. (1999). The Development and Validation of the Globe Culture and Leadership Scales. In R. J. House, P. J. Hanges, P. W. Javidan, G. V. Dorfman, V. Gupta, \& GLOBE-Associates (Eds.), Cultures, Leadership, and Organizations: GLOBE: A 62 Nation Study (Vol. 1). Thousand Oaks, CA: Sage.

Hater, J., \& Bass, B. (1988). Superiors' Evaluations and Subordinates' Perceptions of Transformational and Transactional Leadership. Journal of Applied Psychology, 73, 695-702. https://doi.org/10.1037/0021-9010.73.4.695

Hauser, M., \& House, R. J. (2000). Lead through Vision and Values. In E. Locke (Ed.), Handbook of Principles of Organizational Behavior (pp. 257-273). Malden, MA: Blackwell.

Huang, X., Iun, J., Liu, A., \& Gong, Y. (2010). Does Participative Leadership Enhance Work Performance by Inducing Empowerment or Trust? The Differential Effects on Managerial and Non-Managerial Subordinates. Journal of Organizational Behavior, 31, 122-143. https://doi.org/10.1002/job.636

Huang, X., Shi, K., Zhang, Z., \& Cheung, Y. L. (2006). The Impact of Participative Leadership Behavior on Psychological Empowerment and Organizational Commitment in Chinese State-Owned Enterprises: The Moderating Role of Organizational Tenure. Asia-Pacific Journal of Management, 23, 345-367.

https://doi.org/10.1007/s10490-006-9006-3

Hulpia, H., \& Devos, G. (2010). How Distributed Leadership Can Make a Difference in Teachers' Organizational Commitment? A Qualitative Study. Teaching and Teacher Education, 26, 565-575. https://doi.org/10.1016/j.tate.2009.08.006

Hulpia, H., Devos, G., \& Roseel, Y. (2009). Development and Validation of Scores on the Distributed Leadership Inventory. Educational and Psychological Measurement, 69, 1013-1034. https://doi.org/10.1177/0013164409344490

Hulpia, H., Devos, G., \& Van Keer, H. (2011). The Relation between School Leadership from a Distributed Perspective and Teachers' Organizational Commitment: Examining the Source of the Leadership Function. Educational Administration Quarterly, 47, 728771. https://doi.org/10.1177/0013161X11402065 
Hulpia, H., Devos, G., Rosseel, Y., \& Vlerick, P. (2012). Dimensions of Distributed Leadership and the Impact on Teachers' Organizational Commitment: A Study in Secondary Education. Journal of Applied Social Psychology, 42, 1745-1784. https://doi.org/10.1111/j.1559-1816.2012.00917.x

Jantzi, D., \& Leithwood, K. (1996). Toward an Explanation of Variation in Teachers' Perceptions of Transformational School Leadership. Educational Administration Quarterly, 32, 512-538. https://doi.org/10.1177/0013161X9603200404

Kalshoven, K., Den Hartog, D. N., \& De Hoogh, A. H. (2011). Ethical Leadership at Work Questionnaire (ELW): Development and Validation of a Multidimensional Measure. The Leadership Quarterly, 22, 51-69. https://doi.org/10.1016/j.leaqua.2010.12.007

Kaplan, S. (2000). Human Nature and Environmentally Responsible Behavior. Journal of Social Issues, 56, 491-505. https://doi.org/10.1111/0022-4537.00180

Khuntia, R., \& Suar, D. (2004). A Scale to Assess Ethical Leadership of Indian Private and Public Sector Managers. Journal of Business Ethics, 49, 13-26. https://doi.org/10.1023/B:BUSI.0000013853.80287.da

Kouzes, J. M., \& Posner, B. (2012). The Leadership Challenge: How to Make Extraordinary Things Happen in Organizations (5th ed.). San Francisco, CA: The Leadership Challenge-A Wiley Brand.

Kouzes, J., \& Posner, B. (1988). The Leadership Practices Inventory. San Diego, CA: PfeiVer.

Kouzes, J., \& Posner, B. (2002). The Leadership Challenge (3rd ed.). San Francisco, CA: Josey-Bass.

Kozusznik, B., Paliga, M., Smorczewska, B., Grabowski, D., \& Kozusznik, M. W. (2018). Development and Validation of the Team Influence Relations Scale (TIReS): Beyond the Measurement of Individual Influence in Teams. Baltic Journal of Management, 3, 84-103. https://doi.org/10.1108/BJM-01-2017-0023

Laub, J. A. (1999). Assessing the Servant Organization: Development of the Servant Organizational Leadership Assessment (SOLA) Instrument. Dissertation Abstracts International UMI No. 9921922.

Leithwood, K., \& Duke, D. L. (1999). A Century's Quest to Understand School Leadership. In J. Murphy, \& K. S. Louis (Eds.), Handbook of Research on Educational Administration: A Project of the American Educational Research Association (pp. 45-72). San Francisco, CA: Jossey-Bass Publishers.

Leithwood, K., Jantzi, D., \& Steinbach, R. (1999). Changing Leadership for Changing Times. Philadelphia, PA: Open University Press.

Leithwood, K., \& Jantzi, D. (1999). Transformational School Leadership Effects: A Replication. School Effectiveness and School Improvement, 10, 451-479.

https://doi.org/10.1076/sesi.10.4.451.3495

Mączyński, J., Łobodziński, A., Wyspiański, D., \& Kwiatkowski, P. (2010). Differences on Organizational Practices and Preferred Leader Attributes between Polish Managers Investigated in 1996/1997 and 2008/2009. Polish Psychological Bulletin, 41, 127-132. https://doi.org/10.2478/v10059-010-0017-Z

Miao, Q., Newman, A., \& Huang, X. (2014). The Impact of Participative Leadership on Job Performance and Organizational Citizenship Behavior: Distinguishing between the Mediating Effects of Affective and Cognitive Trust. The International Journal of $\mathrm{Hu}$ man Resource Management, 25, 2796-2810.

https://doi.org/10.1080/09585192.2014.934890

Northouse, P. G. (2001). Leadership: Theory and Practice (2nd ed.). Thousand Oaks, CA: 
Sage.

Nunnally, J., \& Bernstein, I. H. (1994). Psychometric Theory(3rd ed.). New York: McGrawHill.

Odoardi, C., Battistelli, A., Montani, F., \& Peiró, M. (2019). Affective Commitment, Participative Leadership, and Employee Innovation: A Multilevel Investigation. Journal of Work and Organizational Psychology, 35, 103-113.

https://doi.org/10.5093/jwop2019a12

Pan, H. W., Nyeu, F. Y., \& Chen, J. (2015). Principal Instructional Leadership in Taiwan: Lessons from Two Decades of Research. Journal of Educational Administration, 53, 492-511. https://doi.org/10.1108/JEA-01-2014-0006

Patterson, K. (2003). Servant Leadership: A Theoretical Model Graduate School of Business. Doctoral Dissertation, Virginia Beach, CA: Regent University.

Podsakoff, P., Mackenzei, S., Moorman, R., \& Fetter, R. (1990). Transformational Leader Behaviors and Their Effects on Followers' Trust in Leader, Satisfaction, and Organizational Citizenship Behaviors. The Leadership Quarterly, 1, 107-142.

https://doi.org/10.1016/1048-9843(90)90009-7

Posner, B. (2016). Investigating the Reliability and Validity of the Leadership Practices Inventory. Administrative Sciences, 6, 17. https://doi.org/10.3390/admsci6040017

Prabaswari, A., \& Dharmastiti, R. (2019). The Survey on the Perception of Safety and Security Culture for Nuclear Workers. IOP Conference Series: Materials Science and Engineering, 528, Article ID: 012017. https://doi.org/10.1088/1757-899X/528/1/012017

Reed, L., Vidaver-Cohen, D., \& Colwell, S. (2011). A New Scale to Measure Executive Servant Leadership: Development, Analysis, and Implications for Research. Journal of Business Ethics, 101, 415-434. https://doi.org/10.1007/s10551-010-0729-1

Resick, C., Hanges, P., Dickson, M., \& Deuling, J. (2006). A Cross-Cultural Examination of the Endorsement of Ethical Leadership. Journal of Business Ethics, 63, 345-359. https://doi.org/10.1007/s10551-005-3242-1

Sagnak, M. (2016). Participative Leadership and Change-Oriented Organizational Citizenship: The Mediating Effect of Intrinsic Motivation. Eurasian Journal of Educational Research, 62, 181-194. https://doi.org/10.14689/ejer.2016.62.11

Sandage, S., \& Wiens, T. W. (2001). Contextualizing Models of Humility and Forgiveness: a Reply to Gassin. Journal of Psychology and Theology, 29, 201-219. https://doi.org/10.1177/009164710102900302

Spangenberg, H., \& Theron, C. C. (2005). Promoting Ethical Follower Behaviour through Leadership of Ethics: The Development of the Ethical Leadership Inventory (ELI). South African Journal of Business Management, 36, 1-18. https://doi.org/10.4102/sajbm.v36i2.623

Tanner, C., Brügger, A., van Schie, S., \& Lebherz, C. (2010). Actions Speak Louder than Words: The Benefits of Ethical Behaviors of Leaders. Zeitschrift für Psychologie/Journal of Psychology, 218, 225-233. https://doi.org/10.1027/0044-3409/a000032

Virakul, B. (2018). Ethics: The Key Element of Leadership and Organizational Performance. Proceedings of the 11th International Conference on Language, Education, Humanities and Innovation, 38-53.

Wong, K. (1998). Culture and Moral Leadership in Education. Peabody Journal of Education, 73, 106-125. http://www.jstor.org/stable/1493017 https://doi.org/10.1207/s15327930pje7302 5

Yammarino, F. L., Spangler, W. D., \& Bass, B. M. (1993) Transformational Leadership and Performance: A Longitudinal Investigation. The Leadership Quarterly, 4, 81-102. 
https://doi.org/10.1016/1048-9843(93)90005-E

Yukl, G. (1999). An Evaluation of Conceptual Weaknesses in Transformational and Charismatic Leadership Theories. The Leadership Quarterly, 10, 285-305. https://doi.org/10.1016/S1048-9843(99)00013-2

Yukl, G., Mahsud, R., Hassan, S., \& Prussia, G. E. (2013). An Improved Measure of Ethical Leadership. Journal of Leadership and Organizational Studies, 20, 38-48. https://doi.org/10.1177/1548051811429352

Zheng, X., Zhu, W., Yu, H., Zhang, X., \& Zhang, L. (2011). Ethical Leadership in Chinese Organizations: Developing a Scale. Frontiers of Business Research in China, 5, 179-198. https://doi.org/10.1007/s11782-011-0127-2 